\begin{tabular}{|c|c|c|}
\hline $\begin{array}{l}\text { A CASE } \\
\text { STUdy }\end{array}$ & $\begin{array}{l}\text { ADVANCE RESEARCH JOURNAL O } \\
\text { Volume } 5 \mid \text { Issue } 2 \mid \text { December, } 2014 \mid 211-218\end{array}$ & $\begin{array}{l}\text { SOCIAL SCIENCE } \\
\text { e ISSN-2231-6418 }\end{array}$ \\
\hline $0=$ & DOI: 10.15740/HAS/ARJSS/5.2/211-218 & Visit us : www.researchjournal.co.in \\
\hline
\end{tabular}

\title{
The winning woman of hindi cinema
}

Kiran Chauhan* and Anjali Capila

Department of Communication and Extension, Lady Irwin College, Delhi University, DELHI (INDIA)

(Email: kchauhan.4feb@gmail.com)

\section{ARTICLE INFO :}

Received : 27.05.2014

Accepted : 17.11 .2014

KEY WORDS :

Winning Woman, Hindi Cinema

HOW TO CITE THIS ARTICLE :

Chauhan, Kiran and Capila, Anjali (2014). The

winning woman of hindi cinema. Adv. Res. J.

Soc. Sci., 5 (2) : 211-218.

*Author for correspondence

\begin{abstract}
The depiction of women as winners has been analyzed in four sets of a total of eleven films. The first two sets Arth (1982) and Andhi (1975) and Sahib Bibi aur Ghulam (1962), Sahib Bibi aur Gangster (2011), Sahib Bibi aur Gangster returns (2013), explore the woman in search for power within marriage. Arth shows Pooja finding herself empowered outside marriage and without any need for a husband or a lover. Whereas in Aandhi, Aarti wins political power and returns to a loving marital home. In Sahib Bibi aur Ghulam choti bahu after a temporary victory of getting her husband back meets her death. In both films Sahib Bibi aur Gangster and returns, the Bibi eliminates the other woman and gangster, deactivates the husband and wins the election to gain power. she remains married and a Rani Sahiba. In the set of four Devdas makes and remakes (1927-2009) Paro is bold, shy, glamorous and ultimately liberated (Dev, 2009). Chanda moves from the looked down upon, prostitute, dancing girl to a multilingual sex worker who is empowering herself through education and treating her occupation as a stepping stone to empowerment. In this version not only are Paro and Chanda liberated but provide agency to Devdas to move out of his depression and alcoholism. Finally Mother India and Bandit Queen show women's struggle portrayed in stark brutal reality of starvation, child marriage, sexual abuse to emerge as nurturing women who will not tolerate injustice but triumph to achieve success and power - Mother India inaugurates the dam, Phoolan Devi becomes a minister.
\end{abstract}

